\title{
VALENŢE RELIGIOS-MORALE ÎN CÂNTECELE PENTRU COPII DIN CREATIA COMPOZITORULUI DUMITRU GEORGESCU KIRIAC
}

Daniel CAMARÄ

\begin{abstract}
Moral and religious valences in children songs created by the Romanian composer Dumitru Georgescu Kiriac ${ }^{1}$. Dumitru Georgescu Kiriac (1866-1928), a classic composer of children songs and a leading representative of the Romanian musical education, created a musical repertoire for students that is remarkable through its complexity, diversity, naturalness, simplicity and profoundness as well. From his entire creation I have selected for my study the moral-religious songs that can be found in the school textbooks and collections from the first half of the XXth century, as they offer us the possibility of opening new outlooks towards nowadays education. Thus, the presence of these songs make us notice the composer's pursuits and visions regarding the role of music in education, an educational role of shaping characters, the hierarchy of values and of a sound behaviour as well. That is why, the moral-religious songs belonging to D. G. Kiriac's work is meant to enrich not only the children songs' repertoire, but also the students' personality, beautifying their way of being and thinking. We consider that this step is necessary the more so as nowadays, music, including the musical education, is rather seen as a factor of entertainment, its educational dimension being minimized or even neglected.
\end{abstract}

Keywords: Dumitru Georgescu Kiriac, musical education, children songs, moral-religious songs, moral-religious teachings.

"Priest, PhD Student, Faculty of Orthodox Teology at „1 Decembrie 1918” University, Alba Iulia, Romania.

${ }^{1}$ Publicat sub îndrumarea Pr. Prof. Dr. Domin Adam, Universitatea „1 Decembrie 1918” din Alba Iulia, care şi-a exprimat acordul pentru publicare. 


\section{Introducere}

La începutul secolului al XX-lea, Dumitru Georgescu Kiriac a avut un rol determinant în educaţia muzicală românească, prin viziunea sa, prin direcţiile pe care le-a imprimat, prin implicarea sa directă în concretizarea acestora, precum şi prin repertoriul de cântece destinat elevilor. Un loc fundamental în creaţia sa îl are cântecul religios-moral ${ }^{2}$, prezent în toate colecţiile sale destinate copiilor, deoarece, în viziunea sa, acest cântec este esenţial în procesul educaţiei muzicale, dar şi al educaţiei în general.

Rolul cântecului religios-moral este uitat sau neglijat în educaţia muzicală actuală din România, dovadă fiind şi faptul că, în programele şcolare de muzică, acesta este aproape inexistent, fiind, cel mult, inclus la „tradiţii”. În acest fel, atunci când apare prin manuale, cântecul religiosmoral este ceva exterior, ce ţine de domeniul trecutului sau al tradiţiilor, menit să îmbogăţească cultura generală, însă rupt de realitatea concretă a elevului, rolul său educativ nefiind valorificat. Tot pe această linie, potrivit manualelor actuale, copiii din clasele primare, exceptând colindele, nu află nimic despre existenţa cântecelor religios-morale, ajungându-se la situaţia incredibilă în care, prezentându-se conţinutul cântecelor şcolare, să apară temele: „natură şi vieţuitoare, muncă, familie, copilărie, joc, patriotism, obiceiuri, sărbători tradiţionale (Crăciun, Paşte ş.a.)"4, în timp ce tema religios-morală să fie total absentă.

2 În prefaţa culegerii Cântece şi Coruri şcolare, pentru uzul copiilor din şcoalele primare, Ed. a II-a, Bucureşti, Tip. „România Nouă”, Th. Voinea, 1923, p. III, semnată de D. G. KIRIAC, N. BĂNULESCU, şi N. SAXU, ni se spune: , În cântecele acestea, uşoare şi în cea mai mare parte în spiritul naţional, se vorbeşte despre Dumnezeu (cântece religioase), de patrie şi de neam (cântece patriotice) şi de viaţa şi activitatea şcolarilor”. În lucrarea de faţă, am optat şi pentru termenul moral, pentru a evidenţia valoarea educativă, formativă a cântecului religios, căci, aşa cum înţelege şi D. G. Kiriac, un cântec religios nu este închis în biserică (cum e înţeles de multe ori astăzi), ci se extinde în modul de a fi al omului, în viaţa lui de zi cu zi. Astfel, un cântec religios-moral se referă la comuniunea cu Dumnezeu, care ,îl înnoieşte pe om şi reface raporturile sale corecte cu aproapele şi cu mediul înconjurător" (Georgios MANTZARIDIS, Morala creştină, trad. Cornel Constantin Coman, Bucureşti, Edit. Bizantină, 2006, p. 10).

3 Institutul de Ştiinţe ale Educaţiei, Programe şcolare în vigoare, disponibil la: http://programe.ise.ro/Actuale/Programeinvigoare.aspx (accesat la 01.09.2019).

${ }^{4}$ Dumitra RADU, Alina PERȚEA, Muzică şi mişcare, manual pentru clasa a IV-a, sem. al II-lea, Bucureşti, Edit. Aramis Print, 2016, p. 19. 
De aceea, în demersul de faţă ne propunem să aducem în actualitate viziunea unui clasic al muzicii pentru copii cu privire la cântarea religiosmorală, dar şi să evidenţiem câteva coordonate ale acesteia, indispensabilă, din punctul nostru de vedere, pentru educaţia muzicală şi formarea elevului de astăzi. Cercetând scrierile şi cântecele lui D. G. Kiriac, descoperim cum cântecul religios-moral este o prezenţă vie în viaţa şcolarului, nu doar ceva izolat în biserică sau în tezaurul trecutului, ci un fapt concret, cotidian, cu rol educativ, de formare a caracterului, a ierarhiei valorilor şi a unei conduite sănătoase, izvorâtă din comuniunea cu Dumnezeu, cu semenii şi cu lumea în care trăieşte.

\section{D. G. Kiriac (1866-1928) ${ }^{5}$ - clasic al cântecelor pentru copii}

Prin diversitatea şi consistenţa preocupărilor sale, dar şi prin deosebita putere vizionară, care 1-a călăuzit în toate acţiunile sale ${ }^{6}, \mathrm{D} . \mathrm{G}$. Kiriac este „unul din marii ctitori ai culturii muzicale româneşti moderne"7, activând ca profesor, compozitor, dirijor, folclorist, critic muzical, bizantinolog, îngrijitor de ediţii, animator al vieţii muzicale ${ }^{8}$.

Într-o vreme în care copiii învăţau în şcoală o muzică abstractă, bazată pe noţiuni tehnice, exerciţii de citire, intonare şi solfegii, iar modestul repertoriu de cântece pentru şcolari nu provenea din valorificarea muzicii autohtone, ci din cântece străine ${ }^{9}$, D. G. Kiriac se dedică educaţiei muzicale, punând la dispoziţia şcolarilor cântece apropiate de sensibilitatea lor, aranjând melodii populare şi compunând cântece în stil popular pentru elevi ${ }^{10}$, deschizând noi drumuri pentru

5 Pentru date bio-bibliografice, a se vedea: Viorel CosmA, Muzicieni din România, Lexicon bio-bibliografic, vol. V, Bucureşti, Edit. Muzicală, 2002, p. 57; George Breazul, D. G. Kiriac, ediţie îngrijită de Titus Moisescu, Bucureşti, Edit. Muzicală a Uniunii Compozitorilor, 1973, p. 182; Mihail Daniel VlădăREANU, Creaţia corală cu caracter religios a compozitorilor Dumitru Georgescu Kiriac şi Ioan D. Chirescu, Târgovişte, Edit. Bibliotheca, 2018, p. 47.

${ }^{6}$ Liviu Rusu, ,Testamentul creator al lui D. G. Kiriac”, în Muzica, 2/1978, p. 29.

${ }^{7}$ Viorel Cosma, Muzicieni din România, Lexicon bio-bibliografic, vol. V, p. 68.

${ }^{8}$ Ibidem.

${ }^{9}$ George BREAZUL, „Educaţia şi instrucţia”, în P. NiţUlESCU (ed.), Muzica Românească de azi, Bucureşti, Cartea Sindicatului Artiştilor Instrumentişti din România, 1939, p. 480.

10 Zeno VAncEA, Creaţia muzicală românească, sec. XIX-XX, vol. I, Bucureşti, Edit. Muzicală, 1968, p. 186. 
urmaşi ${ }^{11}$. Însufleţit de conştiinţa că ,,soarta muzicii româneşti în şcoală se hotărăşte" ${ }^{2}$, şi-a propus să creeze cântece pentru copii, devenind ,marele maestru al cântecelor de copii"'13. În acelaşi timp, fructificând puterea educativă a muzicii, a ales texte care aveau menirea de a-i conduce pe şcolari către o conştiinţă şi o conduită curată. Astfel, în anul 1898, D. G. Kiriac adresa Ministerului Instrucţiunii un memoriu în care arăta importanţa cântării bisericeşti şi a cântecului popular „,pentru viitorul nostru artistic şi pentru educaţiunea noastră naţională"14. Ministrul Spiru Haret îi răspunde: „Lucrarea al cărei plan mi se prezintă aci fiind de mare însemnătate, pentru cunoaşterea muzicei noastre populare şi bisericeşti, prin urmare pentru perfecţionarea învăţământului nostru muzical, care nu va fi nici naţional, nici raţional pe câtă vreme nu va avea ca fundament geniul muzical al nostru..."15. Preocupările sale nu rămân doar la statutul de intenţie, ci devin realitate la început de secol XX, când publică mai multe culegeri de cântece destinate copiilor $^{16}$, iar modul în care D. G. Kiriac a scris aceste cântece a făcut ca el să devină ,portdrapelul genului" ${ }^{17}$ miniaturii corale.

\section{Rolul cântecului religios-moral pentru copii în viziunea lui D. G. Kiriac}

În general, cântecele pentru copii din creaţia lui D. G. Kiriac, au o forţă educativă intrisecă, izvorâtă din viziunea şi aspiraţiile compozitorului, concretizate în mesajul acestor cântece. În acest sens, este ilustrativ faptul că D. G. Kiriac s-a dedicat total muzicii vocale ${ }^{18}$, cu

${ }^{11}$ Doru PoPovici, Muzica corală românească, Bucureşti, Edit. Muzicală, 1960, p. 81.

12 Nicolae Lungu, „D. G. Kiriac şi frumuseţea simplităţii muzicale”, în Iosif SAVA (ed.), Teritorii muzicale româneşti, Bucureşti, Edit. Eminescu, 1980, p. 121.

${ }^{13}$ George Breazul, D. G. Kiriac, p. 20.

14 Gabriel CocoRA, „Cu prilejul centenarului naşterii lui D. G. Kiriac”, în Biserica Ortodoxă Română, 3-4/1966, p. 391.

${ }^{15}$ Dan SMÂNTÂNESCU, „D. G. Kiriac despre cântarea bisericească orientală”, în Ibidem, p. 395.

16 Vasile VAsILE, Pagini nescrise din istoria pedagogiei şi a culturii românești, București, Edit. Didactică şi Pedagogică, 1995, p. 286-289; Viorel CosMA, Muzicieni din România, Lexicon bio-bibliografic, vol. V, p. 68.

17 Octavian Lazăr Cosma, Hronicul muzicii româneşti, vol. VII, Bucureşti, Edit. Muzicală, 1986, p. 165.

${ }^{18}$ George Breazul, D. G. Kiriac, p. 16. 
text ${ }^{19}$, deoarece aceasta transmite în mod concret ,un conţinut ideic şi emoţional de principii călăuzitoare, edificatoare şi formative în viaţa socială şi în năzuinţele culturale"20. D. G. Kiriac se angajează el însuşi în această operă de educaţie pentru şi prin muzică, ,pentru sănătatea şi înălţarea societăţii noastre. Luând tineri din toate clasele, învăţându-i şi îndemnându-i, dându-le ceva din comoara propriei sale fiinţe, el a exercitat asupra lor una din acele hotărâtoare influenţe care transformă fiinţa omenească. Astfel, cântecul societăţii «Carmen» nu era numai un imn spre frumuseţă, ci o mărturisire de puritate morală" ${ }^{\prime 21}$.

D. G. Kiriac vede puterea educativă a muzicii și prezenţa acesteia în şcoală ,în acelaşi timp ca un mijloc de recreaţie şi ca un stimulent pentru dezvoltarea simţămintelor înalte de frumos, de bine..."22 pentru elevi. Astfel, prin cântec, luptă pentru sănătatea morală a copiilor şi a poporului, călăuzindu-i către valori autentice. Pentru aceasta, scrie cântece pentru copii, dar se şi implică în instituirea societăţilor corale şi instrumentale, cu scopul ,de a evita poporului distracţiile vătămătoare şi costisitoare (cafeneaua, jocurile de noroc şi cârciuma), oferindu-i în schimb petreceri curate şi morale" 23 .

Idealul Binelui şi al Frumosului e prezent în toate cântecele lui D. G. Kiriac, încât putem afirma că acestea vizează, direct sau indirect, formarea personalităţii religios-morale a copilului. Preocupat de cântecele cu caracter religios, în memoriul adresat ministrului cultelor şi artelor, din februarie 1924, D. G. Kiriac afirmă că se poate ocupa „cu alcătuirea repertoriului şcolar pentru cântarea în biserică şi cu organizarea corurilor religioase şcolare de toate gradele" 24 .

Din acest memoriu deducem şi viziunea lui D. G. Kiriac cu privire la binefacerile pe care le are cântarea copiilor în biserică. Astfel, prin cântare, copiii participă activ la slujbă, nefiind spectatori pasivi.

${ }^{19}$ Nicolae Lungu, ,D. G. Kiriac şi frumuseţea simplităţii muzicale”, p. 121.

${ }^{20}$ George Breazul, D. G. Kiriac, p. 16.

21 N. IORGA, Oameni care au fost, III, Bucureşti, Fundaţia pentru Literatură şi Artă „Regele Carol II”, 1936, p. 247-248.

${ }^{22}$ D. G. Kiriac către ministrul Instrucţiunii Publice şi Cultelor, memoriu din iunie 1897,

în D. G. KIRIAC, Pagini de corespondentă , p. 300.

${ }^{23}$ Ibidem, p. 301.

${ }^{24}$ D. G. Kiriac către ministrul Cultelor şi Artelor, memoriu din februarie 1924, în Ibidem, p. 330 . 
Cântecele religioase învăţate în şcoală sunt valorificate imediat în biserică, elevul având bucuria de a transmite şi altora ceea ce a învăţat. Această împărtăşire a cântărilor îl va stimula să dorească el însuşi să muncească mai departe, deoarece, văzându-şi roadele studiului, va avea motivaţia interioară de a studia, de a-şi îmbunătăţi interpretarea şi de a-şi îmbogăţi repertoriul. Frumuseţea cântărilor religioase îl va conduce pe copil la o prezenţă naturală ,neforţată” în biserică, iar apoi către o conduită frumoasă în viaţa de zi cu zi, trăind la modul concret „simţământul binefăcător al religiei” 25 . Deprinderea de a cânta în biserică îl va însoţi pe copil în toată viaţa sa, dorindu-şi mereu - şi la maturitate cântarea în cor, în biserică, în perpetuarea tradiţiilor (colinde, stea, vicleim, pluguşor etc.) sau în diverse acţiuni culturale, prin înfiinţarea „societăţilor corale”, utile pentru „disciplina, solidaritatea şi difuziunea culturii în masa poporului" ${ }^{\prime 26}$. Nu în ultimul rând, cântând în biserică, pot fi identificaţi mai uşor copiii cu calităţi muzicale deosebite, pentru a fi călăuziţi către instituţiile muzicale specializate ${ }^{27}$.

\section{Coordonate religios-morale în creaţia pentru copii a lui D. G. Kiriac}

Privind cântecele pentru copii din creaţia lui D. G. Kiriac, observăm cum pătrundem într-un univers al inocenţei, în care textul şi melodia exprimă sufletul curat al copilului, iar frumuseţea, candoarea şi drăgălăşenia din cântece se identifică cu cele din sufletul copilului. Nu doar cântecele „religioase”, ci şi celelalte cântece vorbesc - direct sau indirect - despre prezenţa lui Dumnezeu în om şi în lume, iar copilul trăieşte această prezenţă printr-un mod de viaţă curat şi frumos, ca manifestare a acestei comuniuni. În această privinţă, este greu de realizat o delimitare pe domenii a acestor cântece, deoarece, de exemplu, în rugăciuni se vorbeşte despre şcoală sau despre natură, iar în cântecele dedicate naturii se vorbeşte despre Dumnezeu. De fapt, D. G. Kiriac nici nu împarte cântecele tematic ${ }^{28}$, ceea ce ne face să înţelegem că, pe de o

\footnotetext{
${ }^{25}$ Ibidem.

${ }^{26}$ Ibidem.

27 Ibidem.

28 În toate lucrările sale, singura clasificare este una tehnică: canoane, cântece la unison, două, trei, patru voci.
} 
parte, cântecul religios nu aparţine unui domeniu separat de celelalte sau de viaţa cotidiană, iar, pe de altă parte, totul se desfăşoară pe fundamentul şi în atmosfera providenţei divine.

În aceste cântece întâlnim o familiaritate şi o naturaleţe a legăturii dintre copil şi Dumnezeu, Cel care nu e undeva departe, izolat de lume, ci e prezent în mod firesc în viaţa omului şi a copilului care cântă, dăruind cu dragoste și binecuvântare, daruri şi purtare de grijă. Un exemplu este cântecul Ca-n toţi anii, cu versuri de Ana Niculescu-Codreanu: , Ca-n toţi anii iară/ Domnul nostru Sfânt,/ Intre noi coboară,/ Aci pe pământ,/ Binecuvântare, Darnic semănând,/ Pe drum, pe cărare,/ Şi-n case, la rând./ Veşnic lângă mine,/ Domnul nevăzut/ Milostiv mă ține/ Subt blândul său scut "29. Marile sărbători - Crăciun, Paşti, Rusalii, însoţite de cântece specifice -, dar şi Duminica, sunt prilejuri de bucurie, comuniune şi recunoştinţă: „Dumnezeu a cuvântat:/ "Şeapte zile Eu v-am dat,/ Şease zile să lucraţi,/ Traiul să vi-l uşuraţi./ Iar a şeaptea-i ziua Mea,/ Sfântă voi o veţi ţinea >,/ Dumnezeu ce-a cuvântat/ De noi toţi va fi urmat»" "30.

Rod al simţirii acestei prezenţe este rugăciunea, ca dialog și comuniune a copilului cu Dumnezeu şi, în acelaşi timp, cu părinţii, cu semenii, cu natura, cu patria şi cu lumea întreagă, precum în Imnul Domnului:

„Doamne, numai tu eşti mare,/ Numai singur Domn,/ Tu din cer păzeşte, Doamne,/ Pe copiii tăi în somn;/ Pe părinţi Tu mi-i păzeşte/ De primejdii şi de rău,/ De necazuri îi fereşte/ Şi-i scuteşte de nevoi./ Dă-ne hrană şi putere,/ Sănătate şi noroc,/ Apără de piatră câmpul/ Şi păzeşte-ne de foc./ Dă-ne zile tot senine,/ Tatăl nostru cel ceresc;/ Îndreptează înspre bine/ Pe poporul românesc" 31 .

În rugăciune, copilul se gândeşte la cei din jur, rugându-se cu stăruinţă pentru cei ce se află în dificultăţi şi pentru întreaga lume, evidenţiindu-se iarăşi comuniunea de dragoste, ce naşte solidaritatea, compasiunea şi întrajutorarea: „,Doamne, Doamne-ndurător,/ Dă lumei noastre ajutor (bis)/La orfani dă pâine,/ La cei răi fă bine,/ Căci

${ }^{29}$ D. G. KIRIAC, Cântece şi coruri şcolare, pentru toate treptele învăţământului, ediţie postumă, îngrijită de Constantin Brăiloiu, Bucureşti, Atelierele Grafice SOCEC\&Co., 1930 , p. 7.

${ }^{30}$ Ibidem, p. 11.

${ }^{31}$ Ibidem, p. 9. 


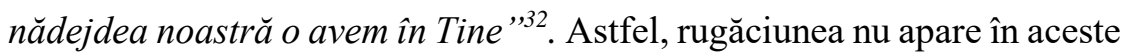
cântece ca un act individual, izolat în casă sau în biserică, ci ca o stare de continuă comuniune, atât în privinţa conţinutului, cât şi a formei, pentru că este vorba despre cântarea în comun. Din punctul de vedere al locului, dat fiind faptul că toate sunt cântece destinate şcolii, elevii cântă şi rugăciunea „la intrarea în şcoală”, Doamne, Doamne, Ceresc Tată... şi „la ieşirea din şcoală”, Toţi, cu inima curată... ${ }^{33}$. Tot pentru cântarea în comun, copiii merg în biserică şi participă activ prin cântările Sfintei Liturghii, care se deosebesc de celelalte cântări, deoarece „rugăciunea trebuie cântată liniştit, fără zbucium ",34, fără interpretare teatrală, ,,căci nuanţele sunt dictate de cuprinsul textului şi de momentul liturgic" "35, şi nu de compozitor. Aceste precizări ale lui D. G. Kiriac ne arată că el vedea cântarea din biserică nu ca pe o interpretare mecanică, ci ca pe o simţire şi trăire a prezenței lui Dumnezeu.

Tot din simţirea prezenţei lui Dumnezeu izvorăşte şi responsabilitatea omului faţă de sine şi faţă de lume. Hărnicia, ca înmulţire a talanţilor, aspiraţiile înalte, curăţia vieţii și virtuţile creştine sunt îndemnuri permanente în aceste cântece, aşa cum este acest Imn, cu versuri de V. Păun:

„Ale gândului avânturi,/ Ale inimei simţiri,/ Prin organe şi prin cânturi/ Le-nălţăm cu mulţumiri./ Ție, Doamne le trimitem,/ Ție astăzi, în adânca veşnicie./ Din lumina Ta divină/ Tu ne-adapi ca din izvor,/ Prin lumină la lumină/ Mintea noastră suie-n zbor./ Suie, Doamne, şi prin Tine vede/ Slava lumii şi în Tine crede./ Tu rodeşti în noi ştiinţa,/ Tainelor cereşti,/ Tu-ntăreşti în noi voinţa/ Şi-n iubirea Ta ne creşti./ Oameni liberi, vrednici de-a lor treaptă,/ Piepturi calde, judecată cât mai dreaptă./ Pentru limbă, pentru lege/ Învățăm să ne jertim,/ Pentru patrie şi rege/ Noi vom şti Români să fim"³.

Dragostea, bunătatea, solidaritatea, recunoştinţa, cuminţenia, smerenia, bucuria, blândeţea, sinceritatea și dragostea de învăţătură sunt

\footnotetext{
32 Ibidem, p. 44.

${ }^{33}$ Ibidem, p. 42.

${ }^{34}$ Idem, Cântările Liturgiei pentru copii şi popor, Târgu Jiu, Institutul de Arte Grafice N. D. Miloşescu, 1926, coperta III.

${ }^{35}$ Ibidem.

${ }^{36}$ Idem, Cântece şi coruri şcolare, pentru toate treptele învăţământului, p. 45.
} 
virtuţi frecvente în cântecele lui D. G. Kiriac, ce se înscriu în acest urcuş al copilului pe calea desăvârşirii, prin modul de viaţă creştin, deoarece „Plinirea tuturor bunătăţilor Tu eşti, Hristosul meu./ Umple de bucurie şi de veselie sufletul meu/Şi ne miluieşte ca un milostiv "37. Pentru aceasta, este necesară promptitudinea în săvârşirea binelui, fiindcă „,Lucrul la timp dăruit/, Preţuieşte îndoit"'38.

Responsabilitatea faţă de lume, ca operă a lui Dumnezeu, căreia El îi poartă de grijă, este ilustrată prin cântecul Ochiul lui Dumnezeu, versuri de G. Coşbuc: „Nimănui să nu-i faci rău/, Că te vede Dumnezeu”39. Tristeţea şi îngrijorarea copilului pentru ,păsărica-n timpul iernii” sunt risipite tot de încrederea în providenţă: ,,Dumnezeu care-a făcut-o,/ Şi pe ea ca şi pe noi,/ O nutreşte şi-o-ncălzeşte/ Şi o scapă de nevoi" (versuri de I. Creangă $)^{40}$.

Pe baza încrederii în Dumnezeu, în toate cântecele pentru copii din creaţia lui D. G. Kiriac este prezentă o stare de siguranţă, o viziune optimistă frumoasă asupra vieţii şi a lumii, chiar şi atunci când lucrurile par a se înrăutăţi. Un exemplu elocvent este şi cântecelul Vine ploaia, cu versuri de G. Coşbuc, ce poate fi educativ şi pentru cei ce anunţă în zilele noastre că vremea „devine rea”, „,se strică” sau ,,e urâtă”, dacă plouă:

„-Vine ploaia! -Las' să vie!/ Bună-i ploaia, toţi o ştie,/ Chiar şi iarba din câmpie.../ -Vine ploaia! -Bine-mi pare!/ În grădină am o floare,/ ploaia mi-o va creşte mare.../ -Vine ploaia! -Bine face!/ Spicul plin acum se coace,/ Spicului răcoare-i place.../ -Vine ploaia! -Las' să vie!/ După ploaie toate-n vie/ În grădină şi-n câmpie...”41.

\section{Concluzii}

În urma acestei incursiuni în cântecele pentru copii create de D. G. Kiriac, am înţeles cum cântecul religios-moral era o prezenţă esenţială şi firească în repertoriile sale, dar şi în Şcoala românească din prima jumătate a secolului al XX-lea.

\footnotetext{
${ }^{37}$ Ibidem, p. 43.

38 Ibidem, p. 36.

${ }^{39}$ Ibidem, p. 12.

${ }^{40}$ Ibidem, p. 66.

${ }^{41}$ Ibidem, p. 63.
} 
Această viziune poate fi benefică şi în zilele noastre, deoarece cântecul religios-moral pentru copii, după cum am observat, nu este o simplă noţiune de cultură generală, despre care se învaţă ceva, ci, atunci când este valorificat, poate avea implicaţii profunde în formarea elevilor, trezindu-le aspirații frumoase și modelându-le caracterul şi conduita.

Prin aceasta, cântecul religios-moral nu aparţine doar domeniului „religios” sau „tradiţional”, aşa cum adesea este înţeles astăzi, ci aparţine vieţii, deoarece comuniunea cu Dumnezeu, transfigurându-1 pe om, înfrumuseţează, implicit, şi relaţiile lui cu semenii şi cu natura înconjurătoare. Astfel, copilul, prin cântec, este condus către această comuniune deplină și binefăcătoare atât pentru el, cât şi pentru cei din jur.

De aceea, considerăm că prezența cântecului religios-moral în Şcoală îmbogăţ̧şte manualul de muzică, repertoriul coral, activitatea cultural-artistică, dar, mai ales, personalitatea elevului care cântă şi, implicit, lumea în care trăim.

\section{Referinţe bibliografice:}

1. BREAZUL, George, „Educaţia şi instrucţia”, în P. Niţulescu (ed.), Muzica Românească de azi, Bucureşti, Cartea Sindicatului Artiştilor Instrumentişti din România, 1939;

2. BREAZUL, George, D. G. Kiriac, ediţie îngrijită de Titus Moisescu, Bucureşti, Edit. Muzicală a Uniunii Compozitorilor, 1973;

3. COCORA, Gabriel, „Cu prilejul centenarului naşterii lui D. G. Kiriac”, în Biserica Ortodoxă Română, 3-4/1966, p. 389-394;

4. Cosma, Octavian Lazăr, Hronicul muzicii româneşti, vol. VII, Bucureşti, Edit. Muzicală, 1986;

5. Cosma, Viorel, Muzicieni din România, Lexicon bio-bibliografic, vol. V, București, Edit. Muzicală, 2002;

6. Institutul de Ştințte ale EduCațieI, Programe şcolare in vigoare, disponibil la: http://programe.ise.ro/Actuale/Programeinvigoare.aspx (accesat la 01.09.2019);

7. IoRga, Nicolae, Oameni care au fost, III, Bucureşti, Fundaţia pentru Literatură şi Artă „Regele Carol II”, 1936;

8. KIRIAC, D. G., Cântările Liturgiei pentru copii şi popor, Târgu Jiu, Institutul de Arte Grafice N. D. Miloşescu, 1926; 
9. KIRIAC, D. G., Cântece şi coruri şcolare, caietul I: 25 cântece pentru una şi două voci, caietul II: 20 coruri şi canoane, pentru 3 şi 4 voci, Bucureşti, 1902 ;

10. KIRIAC, D. G., Cântece şi coruri şcolare, pentru toate treptele învăţământului, ediţie postumă, îngrijită de Constantin Brăiloiu, București, Atelierele Grafice SOCEC\&Co., 1930;

11. KIRIAC, D. G., Pagini de corespondenţă, ediţie îngrijită, prefaţată şi adnotată de Titus Moisescu, Bucureşti, Edit. Muzicală a Uniunii Compozitorilor, 1974;

12. KIRIAC, D. G./BăNulescu, N./SAXU, N., Cântece şi Coruri şcolare, pentru uzul copiilor din şcoalele primare, Ed. a II-a, Bucureşti, Tip. „România Nouă”, Th. Voinea, 1923;

13. LuNGU, Nicolae, „D. G. Kiriac şi frumuseţea simplităţii muzicale”, în Iosif Sava (ed.), Teritorii muzicale româneşti, Bucureşti, Edit. Eminescu, 1980;

14. MANTZARIDIs, Georgios, Morala creştină, trad. Cornel Constantin Coman, Bucureşti, Edit. Bizantină, 2006;

15. POPOVICI, Doru, Muzica corală românească, Bucureşti, Edit. Muzicală, 1960;

16. RADU, Dumitra, PERȚEA, Alina, Muzică şi mişcare, manual pentru clasa a IV-a, sem. al II-lea, Bucureşti, Edit. Aramis Print, 2016;

17. RuSU, Liviu, „Testamentul creator al lui D. G. Kiriac”, în Muzica, 2/1978, p. 29-30;

18. SMÂNTÂNESCU, Dan, „D. G. Kiriac despre cântarea bisericească orientală", în Biserica Ortodoxă Română, 3-4/1966, p. 394-402;

19. VANCEA, Zeno, Creaţia muzicală românească, sec. XIX-XX, vol. I, Bucureşti, Edit. Muzicală, 1968;

20. VAsILE, Vasile, Pagini nescrise din istoria pedagogiei şi a culturii româneşti, Bucureşti, Edit. Didactică şi Pedagogică, 1995;

21. VLĂDĂREANU, Mihail Daniel, Creaţia corală cu caracter religios a compozitorilor Dumitru Georgescu Kiriac şi Ioan D. Chirescu, Târgovişte, Edit. Bibliotheca, 2018. 